\title{
Ghanaian Screendance Perspectives: The Nuance of 'Sankofaism' as Emerging Aesthetics and Rejection of Orthodoxy
}

Samuel Benagr, Department of Theatre Arts, University of Ghana

Terry B.K. Ofosu, Department of Dance Studies, University of Ghana

\begin{abstract}
Screendance is a hybrid art in which choreographic and film techniques are necessary for creating texts where the body dialogues with camera. Ghanaian dance film is best understood within the context of postmodern discourse. This article argues that indigenous and foreign cultural practices are convoluted by morality and hegemonic influence of western culture. Moving from orthodoxy, the Ghanaian dance film recontextualizes dance practice and film techniques into a composite construct with a tinge of Afrocentrism. Framed by critical sankofaism, screendances in Ghana are discussed as being influenced by individual musician's ideas with western biases. Dances for television are shaped by institutional guidelines gleaned from Ghanaian culture. Using Heyba and screendance at TV3 Network and GTV, this article discusses dance films as an emerging aesthetic that re-interprets the function of bodies, their relationships with the camera, and concludes that more than being a hybrid site, screendance in Ghana is a 'polybrid'.
\end{abstract}

Keywords: Screendance, 'sankofaism,' morality, Afrocentrism, aesthetics, hegemony

Africa's contribution, place, and voice in global discourse is quite often obscured and masked. To counteract this tendency, Afrocentrism, as a cultural ideology and worldview, seeks to celebrate the history and achievement of black people. It offers the space for Africans and people of African descent to respond and rewrite their story from the perspective of Africans with the objective of putting right the inaccurate accounts (often imbued with racist connotations) about Africans by non-Africans. Afrocentrism provides an ideological and cultural focus, and agency for selfdetermination. This essay explores Afrocentrism through the notion of 'sankofaism,' which represents a return to beneficial African knowledge systems and cultural practices, including understandings of morality, interwoven with Western cultural influences. In particular, we examine music videos and dance on television as critical 
sites for Ghanaian screendance and the development of 'critical sankofaism,' as an aesthetic.

Dancers, musicians, actors, and artists play important roles in national economic development. For example, a Centre for Economics and Business Research (Cebr) report for Arts Council England, published in July 2015 showed that the arts and culture industry in the U.K. contributed $£ 7.7$ billion as gross value added (GVA) to the British economy. ${ }^{1}$ In Africa, dance performances are often undertaken with a communal spirit, ${ }^{2}$ invariably evincing the voice of the people or that of institutions such as royal, religious, warrior, political and governmental groups. The values, norms and sanctions in African dances are socially constructed and are, for the most part, adhered to by its members. Africa has a youthful population and is usually described as the world's youngest continent. Statistics from the International Year of Youth August 2010-2011 report indicate that in 2010, young people (35 years and below) constituted $70 \%$ of the continent's population. ${ }^{3}$ These youth, including artists, contribute to the economic growth of the continent. Over the years, mostly young and ambitious artists have sought success and fame, and their ambition helps to develop local cultural landscapes that, according to Halifu Osumare, "resist expectations, offer counter-narratives, and amass sociocultural and economic power against social norms of the older generation." 4

In Ghana, screendance is one such form that ambitious musicians and performing artists use to explore their imaginations and creativity. In this paper we use the term screendance to describe the platforms offered to Ghanaian dancers to interact with the camera, often by musicians and television stations, in music videos, and music/dance productions respectively. Music video in this sense refers to a videotaped performance of an electronically recorded popular song usually accompanied by dancing and visual images to interpret the lyrics. Music/dance productions, on the other hand, refer to a live music performance with dancers or a strict dance performance or contest recorded for television. Ghanaian music videos are mostly influenced by the individual musician's ideas, and generally reflect a strong Western influence. Dances for television, on the other hand, are often shaped by institutional guidelines, usually buried in moral or puritanical principles gleaned from the general Ghanaian culture. What defines both artistic approaches are the interwoven Ghanaian identity, normally captured either in the quotidian social movements, or the Afrocentric costumes and scenery. Using the dance film Heyba and screendance on TV3 Network and GTV (Ghana Television), this article discusses the growing phenomenon of dance films in Ghana.

The Ghanaian dance and film landscape underwent slow development until the rise of globalization. In the 1960 s to 1980 s, the Ghanaian film industry was almost entirely state-owned and therefore standards were measured through the moral gaze of Ghanaian society. As shall be discussed in subsequent argument this measurement of 
standards via the moral gaze of the Ghanaian society still pertains. Kwame Gyekye describes the moral gaze as patterns of conduct that are considered most worthwhile and thus cherished by a society, which include principles of behavior and goals of social and individual action. ${ }^{5}$ Broadcasted moving images adhered to strict artistic moral conduct; invariably giving TV stations authority over artworks. Artists whose works were not screened on state-owned televisions were disenfranchised and denied equity. Speaking of the function of media among Western audiences, Rosalind Krauss decries such authority as "disastrous" because the media platforms are "...virtually the only means of verifying its existence as art." ${ }^{\prime 6}$ Despite such criticism of the media, it continues to remain resilient and is arguably one of the most significant sites where humans and the arts interact. ${ }^{7}$

Capitalism was the driving economic ideology during the Ghanaian president John Agyekum Kufuor's government, from 2000-2008, Characterized by privatization, the youth took advantage and perpetuated the capitalist agenda through popular culture, thereby "positioning hiplife ${ }^{8}$ music and style as a primary tool for competing corporate interests." 9 The ability of the newly created artistic product to achieve economic success is dependent on how the artwork appeals to its audiences, the message that it carries and how that is communicated to audiences. As explained by ethnographer Jesse Weaver Shipley, "the affinity between salesmanship and effective lyrical performance marks how hiplife aligns with entrepreneurship." ${ }^{10}$ In parts of the world where poverty is rife, the extent to which an artistic product can be sold underscores its value in society, meaning the economic value of the work can help to combat artistic poverty. This is where private individuals in the arts are vociferous, by making available their appealing and most engaging products.. Paul du Gay et al. in their discussion of advertising make similar observations. They state that as an economic and representational practice, the aim of advertising,

is to make people buy the product, to increase sales and maximize profits. But it is also a cultural practice because, in order to sell, it must first appeal; and in order to appeal, it must engage with the meanings which the product has accumulated and it must try to construct an identification between us - the consumers - and those meanings. ${ }^{11}$

New screendances become both an economic, and culturally representational practice. By this assertion, screendance can be conceived as some form of advertising material for the musician and by extension the television networks.

\section{The Arts in Ghana and the Theories of Local and Global}

Today, globalization has exposed Ghanaians to various media technologies, equipment, and screen-based images. This exposure tempers the orthodox Ghanaian aesthetic consumption, paving the way for the creation of new aesthetics that is best 
explained by what Terry Sprague describes as the "mediazation and aesthetic of consumerism" that characterize contemporary screendance. ${ }^{12}$ The media arouses desires and needs of consumers that they never imagined they had, including for locally produced arts and cultural practices. The central tenet of Ghanaian society with moral conduct as its base - is at a crossroads. There are the (mostly older) lawmakers and money-spinners who uphold the strict moral values as dictates of social behavior, and the youth who embrace the sub-cultural influences of the global village (and who make up the middle and lower class and therefore on the receiving end of the policies). The situation invariably creates two opposing ideologies as theorized by John Collins. He claims that hegemony of the Ghanaian tradition and that of the ruling group is a "repressive" or "centripetal" approach, and the tendency of free expression and creation by the youth as "emancipatory" and/or "centrifugal."13

In Ghana, the arts, and more specifically film and dance, promote indigenous philosophical and ideological perspectives that are given national credence in so far as the various ethnicities contribute to an image of Ghana as a nation. Kwame Gyekye refers to such indigenous philosophies as national orientation or public philosophy, which represent the body of knowledge of a people. ${ }^{14}$ The identity of Ghanaians will therefore be informed by the different cultural practices of the various ethnic groups contributing to the development of national cultural values. Gyekye describes these cultural values as "forms of behavior, practice or thought that are nurtured by a culture and held, cherished and maintained by the users of the culture as most worthwhile and desirable, as having sufficient importance and relevance for their lives." ${ }^{15}$

Ghana has shaped its national identity in part through the representations of some dances, dramas, songs, symbols, maxims, beliefs, and values. ${ }^{16}$ Katharina Schramm explains how after Ghana's independence in 1957, Kwame Nkrumah and his ruling government worked tirelessly to implement new national and cultural policies, to decolonize and reorient independent Ghanaians to embrace a general national identity instead of particular ethnic identities. Schramm further highlights the formation of the Ashanti Cultural Centre and the Institute of African Studies, which played significant roles in Nkrumah's agenda, eventually culminating in the formation of the Ghana Dance Ensemble-a national dance group with members from the different ethnic groups, created to learn and perform the various Ghanaian ethnic dances. ${ }^{17}$ These dances were represented as equally valuable, all adding to the richness and diversity of the new Ghanaian culture and contributing to the creation of a national identity.

The inclusion of maxims, beliefs, and value systems as markers of identity by Nkrumah's government was strategic in facilitating Ghana's decolonization. The Ghanaian local landscape is therefore deeply enmeshed in Ghana's social values, epitomized by its moral values. As part of the Ghanaian ethos, teenagers in the past were required to be sexually ignorant until their initiation rites were performed. ${ }^{18}$ It 
was common knowledge in Ghana that semi-nude pictures and sexually explicit songs and movement were culturally deviant and unacceptable ${ }^{19}$. According to Brigid M. Sackey, however, African "encounters with other cultures, particularly Western, have influenced people to do away with the respect for moral order." 20 This therefore prepares the ground for a cultural collision between the Ghanaian youth and adults.

The result of this collision is what Kwame Gyekye refers to as cultural globalization. Cultural globalization deals with the integration of communities of the world through local cultural activities in a new global village. ${ }^{21}$ Globalization through technological advancement has seemingly brought nations across the world closer together. Different cultures of the world are inadvertently under siege especially from Western capitalism, and it is only the cautious and purposeful countries that can retain their national identities in the convoluted global mix. For the Ghanaian lawmakers, who prefer to adhere to strict regimes of social conduct, the semi-nudity-which Osumare refers to as "deleterious American hip-hop representations" 22 -in many Western pop music videos and films, mostly watched by young people, are problematic. If the Ghanaian youth imbibe some of these 'negative' consumerist artistic approaches, they will transmit them into the new Ghanaian music videos. The comingling of the global and the local has produced various views and taxonomies. Osumare refers to this mix as "internalized structures" or "faces of indigenization" 23 and in similar analysis various scholars have referred to the phenomenon as hybridity, syncretism and appropriation. These taxonomies above are encapsulated in Rolland Robertson's nomenclature "glocalization," ${ }^{24}$ which represents the fusion of new global practices and local antecedents.

Our argument in this article relies on what Gyekye refers to as "critical sankofaism," which is the retrieval of specific old practices to blend with contemporary approaches to new oeuvres. It is distinctive from "naïve sankofaism," which Gyekye defines as "a wholesale revival of the cultural past, irrespective of the functionality or moral worth of particular elements of our (Ghanaian) cultural heritage." ${ }^{25}$ The following section analyzes the different levels of 'sankofaistic' blending that characterize individual 'images of dancing on TV' such as music videos and those produced by television institutions. In what follows, we discuss the music video Heyba (You Are Not on My Level), by the dancehall artist Edem, and Dance Fever Reality Contest by TV3, a private television station in Ghana, as well as GTV's (Ghana's national television station established by former president Kwame Nkrumah) approach to screening dance.

\section{The Heyba Video}

The music video Heyba premièred on 10 November 2012 on the Cine Afrik channel on Multi TV in Ghana. The music video is about the artist's achievement and rise to stardom, and his zeal to conquer and dominate the global music (video) 'territory'. The film has an African-centered presence, a fact reinforced by the artist himself when he 
says "the elements of the song Heyba are actually African." ${ }^{26}$ The wearing of African masks and headdresses together with elaborate cloth and fiber costume play pivotal roles in rituals, such as purification, initiation, exorcism, and others. Apart from shielding the wearer's identity, the spirit is called up to inhabit the mask and then transfer its supernatural potency to the wearer of the mask. ${ }^{27}$ Taking the foregoing view into account, the mise-en-scène in Heyba establishes the connection between the contemporary and traditional, where the two situations co-exist to produce that all-conquering and domineering force characteristic of the might of a tsunami.

In the opening sequence of Heyba, notions of territory, conquest, and dominance are evoked before we see the musician, Edem. The subsequent shot of a female dancer in raffia skirt sets the tone and context for this music video. New technology is democratic in nature. It engenders creative abilities and aids the conceptualization and production values of dance films. Ghanaian youths (typically 18-25) therefore have a platform with which they can express as well as assert themselves. This is demonstrated by this film, for example, in images such as female traditional priests in raffia skirts, muscular men with make-up that is stereotypical of African warriors, and others like the mask, which represents the embodiment of the ancestral spirits and gods of the African continent. We propose that the encounter in the initial sequences portrays Edem's aspirations toward cultural dominance through his strategic combination of creative and artistic abilities with Afrocentric symbolism.

Through shot composition as well as the narrative and lyrical structure, Edem takes center frame. The way the shots are filmed, the story of the music video, and the arrangement of imagery through editing all point toward a contest of some sort. For example, there is an image of Edem on the clouds ${ }^{28}$ which echoes the view expressed in part of the title of the music video; You Are Not On My Level. What competition is being alluded to here? Who is Edem's competition with? And what is the focus and purpose of the competition? Is it for recognition, dominance, or both? An image of a surge of force, power, and strength is seen here that alludes to a "tsunami," 29 the force of which is comparable to the power that resides in this youthful group to impact Ghanaian culture.

The primary visual references in the film include African artistic, literary, and performative elements. Analyzed through a lens of sankofaism, the mask, facial decoration, and bodily ornaments suggest that the emerging Africa is making good use of its cultural heritage to achieve territorial conquest and dominance as suggested at the start of Heyba. Edem's competition for space within the global music market is representative of Africa's quest for recognition and eventual conquest of the same market. In order to "reach for the heavens," as the lyrics suggest, Ghana requires a talented, creative, ingenuous, and capable population. Therefore when we look at the film, we recognize the symbolism of the sequence and movement involving strong and well-built young men and women. Their physical attributes reflect the strength 
that is found in the nation, which must be harnessed in order for it to further develop. Similarly, the priestess dressed in a raffia skirt ${ }^{30}$ with angelic wings is an example of how women in the predominantly patriarchal and Christian Ghanaian society might assert themselves. As a priestess, she is listened to and accorded the respect that her male counterparts take as a given. Edem uses such images symbolically to demonstrate the complementary contributions of females in contemporary Ghana.

The framing of the musician is significant. He is placed mostly at the center of the screen. In the same way, most of the medium and close-up shots in the music video are centered, and, the centered subjects are Afrocentric in essence. This echoes the centrality of African-centered and African-inspired approaches to Africa's quest for dominance in the wider world. The quest and clamor to be "reaching for the heavens" 31 must be perpetuated by Afrocentric ideals and values. But in pursuing the agenda of reaching the desired heights of success, as implied in the music video, creative and enterprising youth, as exemplified by Edem, occupy a middle ground by borrowing and mixing cultures in a typical postmodern approach. Therefore Ghanaian orthodoxy ceases to be the sole bearer of meaning.

In the entire music video, we find only four direct references to Western culture: the microphone at the end of the film, the Absolut Vodka bottle, the speaker, and the Italian wine. The Heyba music video also has indirect references to hip-hop, which in itself has Afrocentric roots. With these references come the workings of hybridity and globalization - selecting what is useful from other (Western) cultures to enhance and advance one's course and mission. Such references make it possible to apply the concept of 'critical sankofaism' in the global world. Indigenous African theories and paradigms, such as the use of masks and body ornaments to evoke strength and power, interface with Western ones, highlighting their hybridity. The minimal use of these foreign codes, sharply contrasted with the dominance of African imagery in the music video, does not undermine the value of this hybridity. Edem's lyric about getting better with time correlates with the Italian wine reference, but also corresponds to an African worldview. Experience and old age is indispensable - note the relevance of the sage old lady in the film. In as much as the youth, exemplified in the music video, have new approaches to improving their conditions and by extension the nation, there is still the need to recognize that in the African cultural setting, wisdom, good counsel, and the experiences of the elderly are indispensable.

The predominance of African percussion instruments in the film strongly aligns with the national policy of Ghana's sitting government for citizens to use products made in Ghana, to improve the nation's efforts towards sustainable economic development. This approach is not a novel concept. It echoes similar calls made in the 1960s by Ghana's first president, Kwame Nkrumah when he said, 
let us begin to look inwards into the African continent for all aspects of its development. Our communications were devised under colonial rule to stretch outwards towards Europe and elsewhere, instead of developing internally between our cities and states. ${ }^{32}$

By extension therefore, the prevalence of African instruments in the video represents the adoption of made-in-Africa solutions for African problems. The importance of socalled homegrown solutions and self-reliance were reinforced during the global financial crisis in 2008. Because Africa was not fully integrated into the global financial system, it was less affected by the economic downturn. ${ }^{33}$ Consequently, the region became one of the fastest growing areas of the world.

The music video seems to suggest that there is energy, power, and vitality in the African mode of life. Furthermore, its dominant Afrocentric imagery coupled with the lyrics can be viewed as a desire for growth. The clip in which the women turn their back to camera ${ }^{34}$ is especially noteworthy. It uses a montage editing technique, and is followed by the image of the speaker to make a strong ideological statement. In keeping with Gyekye's notion of 'sankofaism,' we suggest that the ladies are embarking on a journey to recover their heritage in order to engineer economic growth. They literally turn their backs on practices that are not local and go back to their roots to retrieve the valuable practices that will open the door to higher aspirations. The combination of youthful energy, wisdom of the old, and traditional cultural values enables the African to be victorious on the world stage.

\section{Screendance at TV3 Network and GTV}

In this section we turn our attention to the second platform for screendance in Ghana: the television institution's TV3 Network, which is a private organization, and GTV (Ghana Television), which is a state owned public service. Our interest is in their diverse programming in current trends, traditions, and dance contests. As a public service broadcaster, GTV has a mandate to create programs with cultural, intellectual, or educational merit..$^{35}$ Though both are institutions, TV3 Network is more flexible and able to accommodate morally questionable artworks, ${ }^{36}$ as measured by the Ghanaian adult/government moral perspectives, while GTV is more rigid and therefore censors artistic materials that do not conform to the Ghanaian moral gaze.

In a lecture during the Ghana Broadcasting Corporation's golden jubilee celebrations, communications scholar P. A. V. Ansah asserted that while cultural pluralism is desirable, "it is essential that people should be initially and basically nurtured on their own cultural values so that inevitable external borrowings do not have undue alienating effect." ${ }^{137}$ Recommendations like Ansah's invariably represent the Ghanaian adult/government viewpoints that characterize GTV's censorship approach. This approach by GTV can be appreciated in the context of it being a trustee for national 
interest and therefore broadcasts state-driven representations of culture. ${ }^{38}$ Perhaps inevitably, GTV's audience ratings have decreased over time, and it continues to be bereft of innovative programs that are needed to revitalize the station. In a recent article in the Daily Graphic, Charles Wereko-Brobbey stated: "Sadly, the GBC [GTV] has abandoned its role as a public broadcaster in its attempt to retain its relevance and retain the audiences who are deserting it in droves to the independent alternatives." ${ }^{39}$ GTV's cameramen and editors are set to a very strict code of ethics, conduct, and regime, which does not allow for the wider aesthetic possibilities available in the private sector. ${ }^{40}$ Ansah alludes to this strict control in his lecture: "the effect of this tight control is that objectivity is sacrificed by broadcasters for their survival, and their professionalism is stifled." ${ }^{41}$

In contrast to GTV, we argue that the TV3 Network practices 'critical sankofaism'. TV3 is one of the most patronized television stations in Ghana, which according to Anangfio Jnr. is due to their innovation:

in their quest to give factual meaning to their slogan 'Best In Entertainment', TV3 Network has always come up with entertainment programmes such as Music Music, Hitz Video, Spot Light, Bands Alive, Dance Fever, TV3 Carnival, The Battle and the just ended Ghana's Most Beautiful on its network. They have secured success with those programmes. ${ }^{42}$

Though they allow for creativity with the dancers, musicians, and curators, TV3 still exercises some form of control over their product, ensuring some level of moral scrutiny. ${ }^{43}$ Just like any Ghanaian institution, TV3 is influenced by the moral gaze of society, but being private also allows for some flexibility in its operations. To a large extent, the form and content are all examined to ascertain their moral soundness before they are aired. TV3 Network has a strict rehearsal regime that allows for guidance, orientation, and some level of scrutiny of most artistic presentations before they are staged. ${ }^{44}$ It is at this platform that artists' acts are fine-tuned. However, as a private organization, TV3 Network's scrutiny of dance programs is more relaxed than GTV's:

If you think TV3 has run out of juice after putting together 'Mentor', 'Looking for love' and 'Ghana's Most Beautiful', think again! They are just about to roll out yet another offering for dancers. ${ }^{45}$

Though the above statement may sound like a marketing hype, TV3's success is acknowledged nationwide; in fact the famous Ghanaian footballer Godfred Yeboah was nicknamed TV3 as a result of his on-field brilliance.

Dance Fever is one of the most innovative dance programs of TV3. Ghanaians watched movement from various dance genres, coupled with surprising camera angles and 
shots (through the use of cranes and jibs) that reflected Western approaches. TV3's success seems to be based on innovations exhibited in the coverage and introduction of new programs, which culminates in its popularity nationwide. In fact, months after the completion of Dance Fever, fans still demanded its revival as indicated by Anangfio Jnr.:

If TV3 can revisit their slogan 'Best in Entertainment' then Boogie Down should be taken off air or something really needs to be done about it, I know the concept is just brilliant but the execution is just wrong, it needs more planning. Paa Kwesi Ackom, we are still waiting for Dance Fever. ${ }^{46}$

The above statement is Anangfio's message of displeasure to the producer of Boogie Down Paa Kwasi Ackom, who happens to be the producer of Dance Fever. Ackom, a middle-aged man and a former producer at TV3 Network started most of the new TV shows. By virtue of his age and knowledge in film he was able to blend the old and new schools of thought. He was technically the innovator of TV3 Network and therefore a household name amongst the television fraternity as evidenced in Anangfio's account:

seeing the director of "Music Music" Paa Kwesi Ackom, I was more fired up and listened attentively. I was thrilled seeing him, because the success story of TV3 "Best In Entertainment" slogan will not be written without him. ... this guy is a tough guy for the records. He has the penchant for good productions, when you talk of Music Music, one thing that comes to mind immediately is Paa Kwesi Ackom, and he has brought diversity to the show. ${ }^{47}$

During his tenure as producer, Ackom epitomized the very concept of 'critical sankofaism'. He ensured that any young artist who had to dialogue with his cameras and audiences exhibited a blend of Ghanaian identity and new trends. His approach was recognized and he was nominated for Best Television Producer in the maiden Radio and Television Personality awards in $2011^{48}$ in Ghana.

In a personal interview during Dance Fever, the producer intimated that his influence comes to bear on the production during rehearsals for the show:

We make sure to give the contestants good orientation. Firstly, on their identity as Ghanaians and therefore Africans and insist that it must show in their choreographies. And secondly, that they belong to a global world so they must be current and very innovative. ${ }^{49}$

Ackom's words and approach ring true for the Dance Fever production because it was a 'polybrid' production that had African, Western, and even Latin artistic approaches. In the maiden production the choice of dances reflected the producer's intention to have a global mix. According to TV3's Public Relations Manager Janet Carboo 
Danquah, "Certain dances like ballroom, salsa, the twist and even highlife - the young ones don't know how to really dance. So we are going to teach them how to do it." These many dance genres depicted in the Dance Fever contest show how the global is conflated with the local and how old and new interact: youth learn the local Ghanaian highlife alongside the global ballroom, salsa, and twist dances, and the young dancers also learn old dances.

It is the negotiation of the virtuosic dancing body between intrinsic Ghanaian/Afrocentric colorings, fused with global artistic ideas, which are manipulated by screen technology that makes dancing for the screen in TV3 Network unique. The station has some equipment such as jibs, cranes, lights, and a scenic shop, which offers opportunities for creativity and follows the conventions of television. One of the strengths of TV3 Network is the composition of its mise-en-scène in dance productions. The producers are able to creatively organize elements such as setting, lights, costumes, and figure expression and movements. ${ }^{51}$ The lighting team uses lights to compose shots that delineate African from Western dance movements. They accentuate the texture of the rounded, curvy, and earthy Afrocentrism of contemporary Ghanaian dances, contrasting then with the sharp angular Western postmodern popular dances. It is during programs such as Dance Fever that Ghanaians are able to fathom their unique contributions to global culture.

\section{Conclusion}

As a developing nation, Ghana lacks the sophistication and luxury of Western technology to create screendances purposefully for appreciation. In this article we have argued that screendance in Ghana is constituted by dances in music videos and those performed in television institutions. We have also argued that globalization has introduced technological advancement and other foreign cultures, more specifically Western culture that sometimes subverts some Ghanaian indigenous moral codes. We have argued how the application of 'critical sankofaism' in various measures by institutions such as TV3, GTV, and individual musicians such as Edem, bring the Ghanaian moral order and identity in the complex global mix.

The paper also postulates that the interface of Western and Ghanaian culture has resulted in the abandoning of the old orthodox approach. The creation of new aesthetics re-contextualizes Ghanaian screendance as part of the Afrocentric approaches into what can largely be referred to as cultural globalization. The Africanthrough 'critical sankofaism' - is able to connect local culture to the 'polybrid' global culture. It is at this stage that the notion of Afrocentrism comingles with the global cultures. 


\section{Biographies}

Dr Samuel Benagr is a lecturer at the School of Performing Arts, University of Ghana, Legon-Accra. Benagr teaches courses in Media Arts and Theatre Arts at undergraduate and graduate levels. Benagr's research interests are in the area of cinema and new technologies and identity construction, with emphasis on West African video filmmaking. He is a contributing author of Directory of World Cinema - Africa. Some ongoing research works include re-reading early Ghanaian video film practice in the context of neorealism, Ghanaian 2012 elections; the aftermath and lessons going forward, the performing arts and peace building in Ghana.

Email: sbenagr@ug.edu.gh

Terry Bright Kweku Ofosu is an assistant lecturer at the Department of Dance Studies, School of Performing Arts, University of Ghana, Legon-Accra, where he has been teaching since 2011. Ofosu is currently a PhD student at the Institute of African Studies at the same university, with special interest in popular dance narratives within the Ghanaian socio-political landscape. As a choreographer and videographer (director and editor), Ofosu's passion is in researching within/across both terrains. Ofosu presently awaits a research publication on globalization and hip-hop dance cypher, with Oxford University Press.

Email: terryofosu@yahoo.com

\section{Notes}

${ }^{1}$ Cebr report, Contribution of the Arts and Culture.

${ }^{2}$ Gloria Fiero, The Humanistic Tradition, 100.

${ }^{3}$ International Year of Youth.

${ }^{4}$ Halifu Osumare, The Hiplife in Ghana, 83.

${ }^{5}$ Kwame Gyekye, African Cultural Values, 55.

${ }^{6}$ Rosalind Krauss, "Video: The Aesthetics of Narcissism," 59.

7 P. A. V. Ansah, Ghana Broadcasting Corporation, 28.

${ }^{8}$ Hiplife is a hybrid music genre of hip-hop and Ghanaian highlife.

${ }^{9}$ Osumare, 120.

${ }^{10}$ Jesse Weaver Shipley, "Aesthetic of the Entrepreneur," 642.

${ }^{11}$ Du Gay et al, Doing Cultural Studies, 25.

${ }^{12}$ Terry Sprague, "Screendance: Aesthetics of Media and Consumer Visual Culture," 61.

13 John Collins, "One Hundred Years of Censorship in Ghanaian Popular Music," 171. 
${ }^{14}$ Gyekye, Philosophy, Culture and Vision, 159.

${ }^{15}$ Ibid.

${ }^{16}$ Francis Nii-Yartey, "Performing Arts: Identity and the New Social Paradigm," 284-289.

${ }^{17}$ Katharina Schramm, "The Politics of Dance," 343

${ }^{18}$ Peter Sarpong, Ghana in Retrospect, 69.

${ }^{19}$ Paschal Yao Young, Music and Dance Traditions of Ghana, 162.

${ }^{20}$ Brigid M. Sackey. "African Worldviews," 160.

${ }^{21}$ Kwame Gyekye, Origins of Globalization, 126.

${ }^{22}$ Osumare, 15.

${ }^{23} \mathrm{Ibid}$.

${ }^{24}$ Ronald Robertson, "Glocalisation," 26.

${ }^{25}$ Kwame Gyekye, Philosophy, Culture and Vision, 159.

${ }^{26}$ Ernest Dela Aglanu, "No Video Released This Year Can Match My Heyba - Edem."

${ }^{27}$ See Fiero.

28 "Heyba" music video, 00:02:15

${ }^{29}$ Idem., lyric 00:00:26 to 00:00:27

${ }^{30}$ Idem., from 00:00:26 to 00:01:10

${ }^{31}$ Idem., lyric 00:01:21 to 00:01:22

${ }^{32}$ Kwame Nkrumah, Africa Must Unite, 219.

${ }^{33}$ John, Katunga (Regional Technical Advisor, CRS East Africa Regional Office) made this declaration during at a training workshop organized by the CRS Institute for Peace in Africa at GIMPA in Accra, Ghana. The theme of the workshop was "Equipping The Youth To Be The Leaders And Champions For Peace, Reconciliation And Good Governance In Africa." From 23 - 28 June, 2014.

34 "Heyba" music video, from 00:02:31 to 00:02:32

${ }^{35}$ Ansah, Ghana Broadcasting Corporation, 8.

${ }^{36}$ Birgit Meyer, Sensational Movies, 7.

${ }^{37}$ Idem., 31

${ }^{38}$ Ibid.

${ }^{39}$ Charles Wereko-Brobbey, "Suspend TV License Fee; It is a Bad Law," 44.

${ }^{40}$ Meyer, 6.

${ }^{41}$ Ansah, 26.

${ }^{42}$ Ebenezer Anagfio Jnr., "TV3, What is Boogie Down all about." 19 August 2009. http://www.ghanacelebrities.com.

${ }^{43}$ Paa Kwesi Ackom qtd. in Terry B. Ofosu, "Interview at TV3."

${ }^{44} \mathrm{Ibid}$.

${ }^{45}$ Jive, "Dance fever."

${ }^{46}$ Ibid.

${ }^{47}$ Ibid.

${ }^{48}$ Ernest Dela Aglanu, "Multi media others to receive honorary awards."

${ }^{49}$ Paa Kwesi Ackom qtd. in Ofosu

50 Jive.

${ }^{51}$ Michael Rabiger. Directing the Documentary, 589. 


\section{References}

Aglanu, Ernest Dela. "Multi media others to receive honorary awards." Posted 15 August 2011. http://entertainment.myjoyonline.com/pages/news/201103/62753.php. “No Video Released This Year Can Match My Heyba - Edem." Posted 9 November 2012. http://entertainment.myjoyonline.com/pages/news/201211/96999.php.

Anagfio Jnr., Ebenezer. "TV3, What is Boogie Down all about.” Posted 19 August 2009. http://www.ghanacelebrities.com.

Ansah, P.A.V. Ghana Broadcasting Corporation: Golden Jubilee Lectures, Accra: Ghana Broadcasting Corporation, 1989.

Cebr Report for Arts Council England. "Contribution of the arts and culture industry to the national economy." London: Cebr, 2015.

Collins, John. "One Hundred Years of Censorship in Ghanaian Popular Music." Popular Music Censorship in Africa. Eds. Michael Drewett and Martin Cloonan. Hampshire: Ashgate Publishing Limited, 2006.

Du Gay, Paul, Stuart Hall, Linda Janes, Hugh Mackay, Keith Negus. Doing Cultural Studies: the Story of the Sony Walkman. London: Thousand Oaks, Sage Publications, 1997.

Fiero, K. Gloria. The Humanistic Tradition: the European Renaissance, the Reformation, and Global Encounter. New York: McGraw Hill Publishers, 2002.

Gyekye, Kwame. African Cultural Values: An Introduction. Accra: Sub-Saharan Publishers, 2013.

. "Understanding Globalization." Globalization. Accra: Ghana Academy of Arts and Sciences (GAAS), 2006. 111-131.

. Philosophy Culture and Vision: African Perspectives. Accra: Sub-Saharan Publishers, 2013.

"Heyba." Dir. GYO Gyimah. Edem. 2012. YouTube.

https://www.youtube.com/watch?v=rrLsW4yzwQI.

International Year of Youth: Dialogue and Mutual Understanding. "Regional Overview: Youth in Africa." 2010. http://social.un.org/youthyear/launch.html. 
Jive. "Dance fever: Another TV reality show." Posted 25 April 2007. http://www.modernghana.com/music/4374/3/dance-fever-another-tv-realityshow.html.

Krauss, Rosalind. "Video: The Aesthetics of Narcissism." October 1 (1976): 50-64.

Meyer, Birgit. Sensational Movies: Video, Vision, and Christianity in Ghana. California: University of California Press, 2015.

Nii-Yartey, Francis. "Performing Arts: Identity and the New Social Paradigm" Identity Meets Nationality: Voices of the Humanities, Eds. Helen Lauer, Nana A.A.Amfo and Jemima A. Anderson. Accra: Sub Saharan Publishers, 2011. 282-297.

Nkrumah, Kwame. Africa Must Unite. London: Panaf, 1963.

Ofosu, Terry B.K. Interview at TV3 with Paa Kwesi Ackom, 20 January 2009.

Osumare, Halifu. The Hiplife in Ghana: West African Indigenization of Hip-Hop. New York: Palgrave Macmillan, 2012. http://dx.doi.org/10.1057/9781137021656

Rabiger, Michael. Directing the Documentary. Oxford: Elsevier/ Focal Press, 2004.

Robertson, Ronald. "Glocalization: Time-Space and Homogeneity-Heterogeneity," Global Modernities. Eds. Mike Featherstone, Scot Lash, and Ronald Robertson. London: Sage Publications, 1995. http://dx.doi.org/10.4135/9781446250563.n2

Sackey M.Brigid. "African Worldviews" Africa in Contemporary Perspective: A Textbook for Undergraduate Students. Eds. Takyiwaa Manuh and Esi Sutherland-Addy. Accra: SubSaharan Publishers, 2013. 151-164.

Sarpong, Peter. Ghana in Retrospect: Some Aspects of Ghanaian culture. Accra: Ghana Publishing Corporation, 1974.

Schramm, Katharina. "The Politics of Dance: Changing Representation of the Nation in Ghana." Spectrum Africa. 35.3 (2000): 339-358.

Shipley, Jesse W. "Aesthetic of the Entrepreneur: Afro-Cosmopolitan Rap and Moral Circulation in Accra, Ghana' Anthropological Quarterly. 82(3) (2009): 631-668. http://dx.doi.org/10.1353/anq.0.0074

Sprague, Terry. "Screendance: Aesthetics of Media and Consumer Visual Culture". The International Journal of Screendance. 2 (2012): 61-63

Taylor, Lisa. and Andrews Willis. Media Studies: Texts Institutions and Audiences. Oxford: Blackwell Publishers Limited, 1999. 
Wereko-Brobbey. "Suspend TV licence fee; it is a bad law." Daily Graphic: No. 19824. Tuesday, July 21, 2015.

Young, Y. Paschal. Music and Dance Traditions of Ghana: History Performance and Teaching. North Carolina: McFarland \& Company Inc. Publishers, 2011. 